Images in...

\title{
Penile incarceration secondary to a penile ring device
}

\author{
Deirdre Mary Fanning \\ Department of Urology, Beaumont Hospital, Dublin, Ireland \\ Correspondence to Deirdre Mary Fanning, fanningdee@yahoo.co.uk
}

\section{DESCRIPTION}

A man presented to the emergency department with severe penile pain and swelling. The patient had placed an industrial standard metal ring on his penis approximately $5 \mathrm{~h}$ prior to presentation to enhance sexual pleasure. He had consumed approximately 72 units of alcohol over the preceding 3 days. Examination of the scrotum and testes was unremarkable. The penis was grossly swollen distal to a metallic ring visible at the penoscrotal junction (figure 1). Closer inspection revealed that the ring mechanism

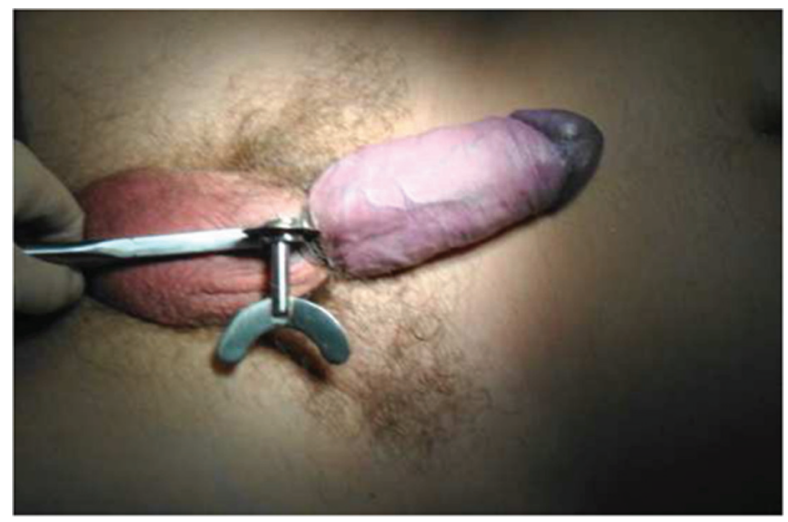

Figure 1 Incarcerated penis is evident with the constrictive metal ring located near the peno-scrotal junction. A ring cutter is placed between the skin and ring.

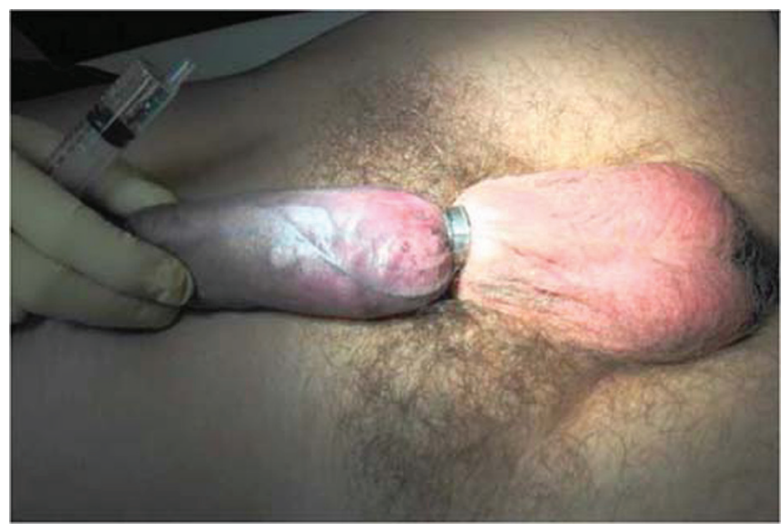

Figure 2 View of the penis following removal of the outermost metal ring. consisted of two rings of differing diameters. The external ring moved in a circular manner over the internal ring. A ridge was present on the inner broader ring, preventing removal of the outer ring (figure 2). The glans penis appeared cyanosed. Penile pulsation was present and sensation was intact. Attempts to manually decompress the penis and remove the constricting ring were unsuccessful. The patient refused all forms of analgesia and anaesthesia. The combination of a stainless steel large ring cutter, a hand held rotary saw and pliers successfully removed the ring. ${ }^{1}$ Local fire services assisted in the procedure. Regular cold water sprays were used throughout the removal process to prevent thermal burns from the mechanical stress of cutting and sawing. ${ }^{2}$ An expander tool, requiring substantial strength was then used to remove the ring. The procedure took approximately $90 \mathrm{~min}$ to complete and was well

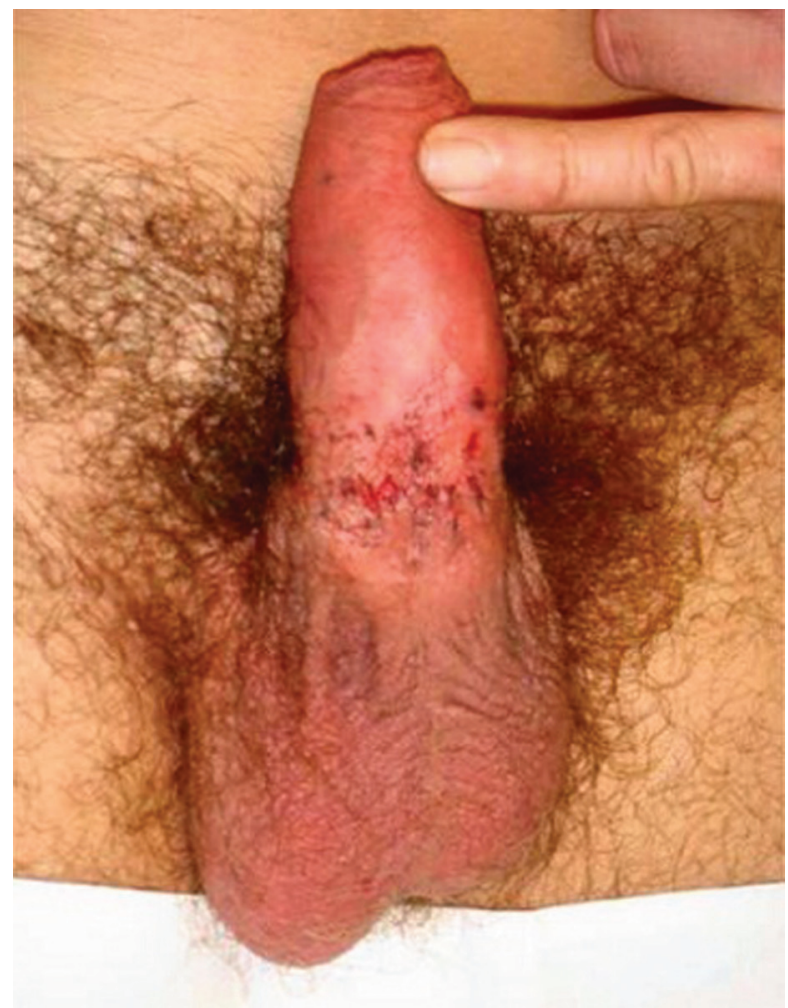

Figure 3 View of the penis following removal of both metal rings. Areas of abrasion are evident. 


\section{BMJ Case Reports}

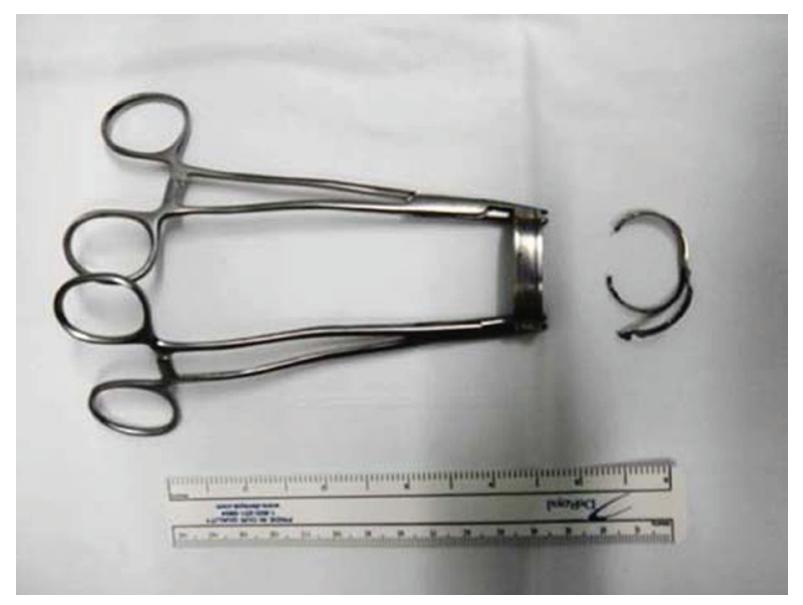

tolerated. Following removal of the ring, the penis rapidly detumesced (figures 3 and 4). A strong pulsation was palpable throughout the penis. Penile sensation was intact. There were no long-term adverse sequelae.

Competing interests None.

Patient consent Not obtained.

\section{REFERENCES}

1. Detweiler MB. Penile incarceration with metal objects-a review of procedure choice based on penile trauma grade. Scand J Urol Nephrol 2001;35:212-17.

2. Xu T, Gu M, Wang H. Emergency management of penile strangulation: a case report and review of the Chinese literature. Emerg Med J 2009;26:73-4.

Figure 4 View of the metal rings on removal. The inner ring had an external diameter of $1.95 \mathrm{~mm}$, internal diameter of $1.85 \mathrm{~cm}$ and a width of $0.8 \mathrm{~cm}$. The outer ring had an external diameter of 2.16 $\mathrm{cm}$, internal diameter of $2 \mathrm{~cm}$ and a width of $0.5 \mathrm{~cm}$. The external ring moved in a circular manner over the internal ring. A ridge was present on the inner broader ring, preventing removal of the outer ring.

This pdf has been created automatically from the final edited text and images.

Copyright 2011 BMJ Publishing Group. All rights reserved. For permission to reuse any of this content visit

http://group.bmj.com/group/rights-licensing/permissions.

BMJ Case Report Fellows may re-use this article for personal use and teaching without any further permission.

Please cite this article as follows (you will need to access the article online to obtain the date of publication).

Fanning DM. Penile incarceration secondary to a penile ring device. BMJ Case Reports 2011;10.1136/bcr.05.2011.4174, date of publication

Become a Fellow of BMJ Case Reports today and you can:

- Submit as many cases as you like

- Enjoy fast sympathetic peer review and rapid publication of accepted articles

- Access all the published articles

- Re-use any of the published material for personal use and teaching without further permission

For information on Institutional Fellowships contact consortiasales@bmjgroup.com

Visit casereports.bmj.com for more articles like this and to become a Fellow 